
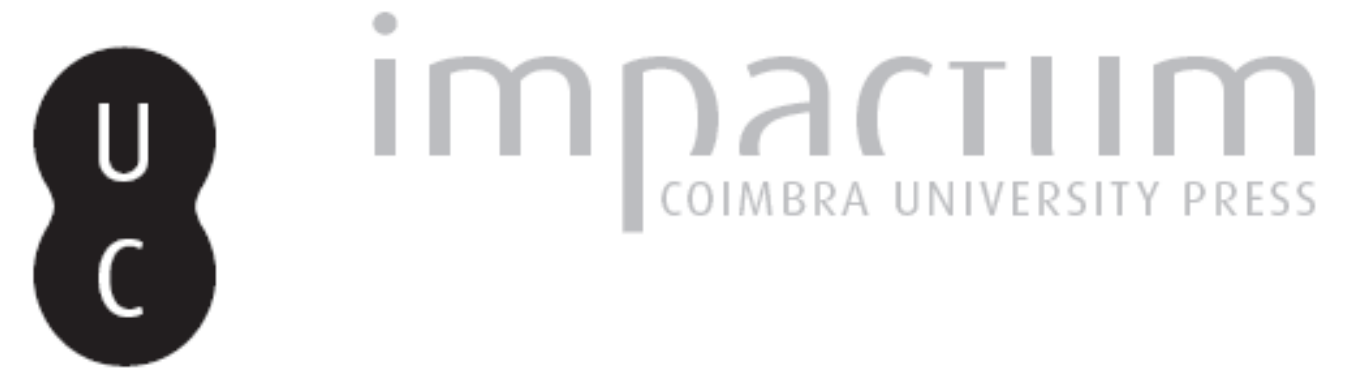

\title{
Sobre a epigrafia romana de Aeminium
}
Autor(es):
Redentor, Armando
Publicado por: Faculdade de Letras da Universidade de Coimbra/lmprensa da Universidade de Coimbra

URL persistente:

URI:http://hdl.handle.net/10316.2/41869

DOI:

DOI:https://doi.org/10.14195/1647-8657_55_6

Accessed : $\quad$ 26-Apr-2023 15:36:02

A navegação consulta e descarregamento dos títulos inseridos nas Bibliotecas Digitais UC Digitalis, UC Pombalina e UC Impactum, pressupõem a aceitação plena e sem reservas dos Termos e Condições de Uso destas Bibliotecas Digitais, disponíveis em https://digitalis.uc.pt/pt-pt/termos.

Conforme exposto nos referidos Termos e Condições de Uso, o descarregamento de títulos de acesso restrito requer uma licença válida de autorização devendo o utilizador aceder ao(s) documento(s) a partir de um endereço de IP da instituição detentora da supramencionada licença.

Ao utilizador é apenas permitido o descarregamento para uso pessoal, pelo que o emprego do(s) título(s) descarregado(s) para outro fim, designadamente comercial, carece de autorização do respetivo autor ou editor da obra.

Na medida em que todas as obras da UC Digitalis se encontram protegidas pelo Código do Direito de Autor e Direitos Conexos e demais legislação aplicável, toda a cópia, parcial ou total, deste documento, nos casos em que é legalmente admitida, deverá conter ou fazer-se acompanhar por este aviso.

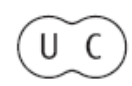


CONIMBRIGA

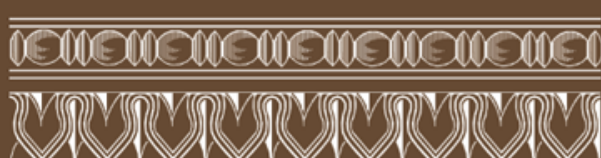

INSTITUTO DE ARQUEOLOGIA

VOLUME LV • 2016

FACULDADE DE LETRAS
UNIVERSIDADE DE COIMBRA 
ARMANDO REDENTOR

Centro de Estudos de Arqueologia, Artes e Ciências do Património /

Universidade de Coimbra (CEAACP/UC)

aredentor@gmail.com

SOBRE A EPIGRAFIA ROMANA DE AEMINIUM

ABOUT AEMINIUM'S ROMAN EPIGRAPHY

"Conimbriga" LV (2016) p. 57-89

https://doi.org/10.14195/1647-8657_55_6

Resumo: Revisita-se o dossiê epigráfico da cidade romana de Aeminium, a actual Coimbra, integrando-o no seu urbanismo e na sua história. Realiza-se a análise revisória dos suportes epigráficos e dos conteúdos iconográficos e escritos, nomeadamente da onomástica e relações familiares, acompanhada de inferências sobre o estatuto jurídico e perfil social dos indivíduos.

Palavras-chave: Sociedade, Cultura, Urbanismo, Lusitânia, Antiguidade.

Abstract: The epigraphic dossier of the Roman city of Aeminium, the contemporary Coimbra, is revisited and integrated in local urbanism and history. The revision analysis of the epigraphic supports and also of the iconographic and written contents, namely onomastics and family relations, is carried out along with inferences about legal status and social profile of individuals.

KeYwords: Society, Culture, Urbanism, Lusitania, Antiquity.

Conimbriga, 55 (2016) 57-89 
Página deixada propositadamente em branco 


\section{SOBRE A EPIGRAFIA ROMANA DE AEMINIUM}

Tendo sido na vetusta Universidade de Coimbra que José d'Encarnação exerceu o seu múnus de professor de Epigrafia e onde, com ele, ganhámos autonomia para este fascinante mundo das inscrições antigas, sem as quais não é possível verdadeiramente versar sobre a Antiguidade Clássica, vamo-nos centrar naquelas que respeitam à cidade romana do Ocidente lusitano à qual se sobrepôs a Coimbra hodierna.

O panorama da paisagem epigráfica dessa urbe não é hoje substancialmente diferente daquele que se reconhecia em finais da década de 70 do século transacto, quando José d'Encarnação realizou as suas Notas sobre a epigrafia romana de Coimbra (Encarnação 1979), a pretexto das primeiras jornadas do Grupo de Arqueologia e Arte do Centro. De facto, de então até ao presente, às quinze lápides nesse momento arroladas pouco mais há a acrescentar que altere substancialmente o entendimento do hábito epigráfico associado a esta cidade lusitana. Apenas os trabalhos arqueológicos realizados na área do espaço forense da cidade romana, entre os anos 1992 e 1997, permitiram incrementar o número de inscrições, nomeadamente com uma peça escultórica esgrafitada (CARVALHO 1998) ${ }^{1}$.

É factualmente aceite que a cidade romana que precedeu a Colimbria medieval (FigueIredo 1884, 87-91; MANTAS 1992, 513; AlarCão $2008,27)^{2}$ teve por nome Aeminium. Esta designação toponímica cons-

${ }^{1}$ Há também a referir um conjunto de 23 fragmentos de epígrafes em depósito no Museu Nacional Machado de Castro, dados a conhecer neste período (CARvalHo 1993), apenas pelo facto de não ser descartável a hipótese de algum deles ter origem na própria cidade de Coimbra, ainda que seja mais provável a relação com Conimbriga ou, inclusive, com outros locais da região. Não obstante, como a sua origem não se encontra deslindada, não podem validar-se neste estudo.

${ }^{2}$ Esta designação medieva deriva do topónimo relativo à vizinha cidade romana de Conimbriga, situada a sul do Mondego, sendo imputável à transferência do bispado

Conimbriga, 55 (2016) 57-89 
tava das fontes clássicas (Plin., NH, 4.113 e 118; Ptol., 5.5 Itin. Anton., 421, 5). Concretamente, Plínio, que igualmente alude à situação do rio que ladeia a cidade, quer como Aeminium ( $N H, 4.113)$, quer como Munda (NH, 4. 115), incluiu-a entre os oppida stipendiaria do Ocidente lusitano, mas, até finais do século XIX, a sua localização esteve sujeita a discussão, precisamente até ao aparecimento, em Abril de 1888, de um monumento epigráfico notável que põe termo à demanda (FIGUEIREDO 1888a).

Este corresponde a inscrição descoberta ao fundo da Couraça dos Apóstolos (n. ${ }^{\circ}$ 1) e que é uma dedicatória realizada a Constâncio Cloro pela ciuitas Aeminiensis ${ }^{3}$. O achado resolve definitivamente a questão da localização do oppidum citado por Plínio, mas permite abrir simultaneamente duas frentes de investigação: uma referente ao seu significado arqueológico perante a estrutura urbana da cidade romana, outra vinculada à discussão do estatuto desta em face da sua designação como ciuitas.

No respeitante ao último aspecto, a questão que se tem colocado aos investigadores prende-se exactamente com a discussão do estatuto jurídico que assumiu a cidade: significa a designação ciuitas Aeminiensis atestada epigraficamente no dealbar do século IV que não terá sido privilegiada com o estatuto municipal?

daí para o assento que foi da Aeminum romana, por volta de 585, a qual acarreta que a designação eclesiástica paulatinamente ofusque os pergaminhos cívicos desta urbe, culminando, plausivelmente durante o domínio muçulmano, na alteração toponímica que sustenta o nome actual (MANTAS 1992, 513; AlarCão 2008, 71-79).

${ }^{3}$ Encarnação $(1979,173)$ precisou a datação do monumento dos anos 305 306, com base em critérios de datação internos ao texto, nomeadamente associados à nomenclatura imperial, e argumentou razoavelmente no sentido de contrariar posições dubitativas quanto à sua autenticidade, a qual aceitamos sem reserva, mesmo tendo em conta a inusitada fórmula que abre o texto e a particularidade de fonética sintáctica que se lhe associa. Quanto a este último aspecto, encontra-se perfeitamente adquirida a existência do dobrete $a d / a t$, aspecto que originalmente decorre do ensurdecimento da consoante final da preposição em face de consoante surda (VÄÄNÄNEN 1988³, 125). Concomitantemente, também consideramos o texto completo, não carecendo da presunção de uma linha inicial em falta, e que só poderia ter existido na molduragem para uma leitura [In honorem / e] t aucmentum, cf. Rodrigues (1959-1960, 114), tendo em vista Figueiredo (1888a) e CIL II 5239, ainda que essas propostas tenham sido aferidas (FIgueIREDo $1888 \mathrm{c}$ e p. 1031 do suplemento ao CIL II) -, ou, inclusive, de se considerar truncado o início da primeira linha - cf. Encarnação (1979, 173, n. 1), propondo $[$ B(onum $)$ e $]$ t aucmentum.

Conimbriga, 55 (2016) 57-89 
Apesar de comummente se considerar que Aeminium assumiu um estatuto municipal (Le Roux e Fabre 1971, 121; ENCARnaÇão 1979, 175; Alarcão 1990, 26-27, 33; Gorges 1990, 96; Mantas 1992, 492-493; Carvalho 1998, 180-184; Le Roux 2010, 192), a realidade é que não existem dados que inequívoca e explicitamente confirmem que o terá alcançado, pelo que a sua consideração é objectivamente dubitativa (cf. Le Roux 1990, 41 e 46; ANDREU 2004, 165-166). Mas tão-pouco a dedicatória a Constâncio Cloro pode ser esgrimida como prova em sentido contrário, assumindo que ao estatuto de ciuitas peregrina duma primeira fase, coincidente com a sua constituição no contexto de uma primígena organização administrativa do território de matriz augustana ${ }^{4}$, apenas se somou o direito latino com a iniciativa de Vespasiano de o estender a toda a Hispânia pelos anos de $70 / 71^{5}$. Realce-se que o uso epigráfico do termo ciuitas, cujo significado estrito remete para um conceito de comunidade autónoma que no período imperial corresponde ao nível básico da orgânica provincial $(O C D, 321$, s. v. civitas,), poderá não ser excludente de um estatuto municipal, aplicando-se por vezes a cidades cuja condição privilegiada está perfeitamente documentada, sendo, inclusive, reconhecido que essa designação granjeia sucesso no período baixo-imperial (cf. Bost e Fabre 1983, 29-35; Le Roux 1990, 43; Dondin-Payre 1997, 287; Hainzmann 1999). Neste sentido, o seu uso também estaria, decerto, sob influência de variações regionais da cultura epigráfica. O estatuto municipal é, deste modo, inseguro, mas crível como encaminhamento lógico da atribuição do ius Latii, enquanto medida que permite a reunião de condições para que tal possa acontecer, e até levando em conta o argumento comparativo (Le RouX e FABRE 1971, 121; ENCARNAÇÃo 1979, 175; AlarCÃo 1990, 26-27; Gorges 1990, 96)

${ }^{4} \mathrm{O}$ miliário de Calígula aparecido nas estruturas do antigo castelo de Coimbra ou próximo (CIL II 4639), que não incluímos neste dossiê pelo facto de a sua implantação original ser alheia à cidade - correspondendo, plausivelmente, à zona de Eiras, a norte da urbe (ALARCÃo 2008, 30-31) -, aponta neste sentido: a indicação de distância de quatro milhas só pode ser contada a partir de Aeminium enquanto caput ciuitatis (MANTAS 1992, 492), do mesmo modo que a do miliário da Mealhada, igualmente datado de 39 d. C., que assinala a milha doze (CIL II 4640).

${ }^{5}$ Não perfilhamos da concepção de que a extensão do ius Latii tenha significado um acesso automático à municipalidade. Com respeito a esta problemática e à datação da iniciativa de Vespasiano, veja-se síntese em Caballos Rufino (2001). 
de que a vizinha cidade de Conimbriga o terá atingido (cf. ANDREU 2004, 166-167).

Uma vez que não podemos abordar cabalmente este assunto complexo nestas linhas, passamos à lição que o monumento pode oferecer em termos de leitura urbana.

A cronologia da dedicatória reforçada pela localização da sua descoberta - em reaproveitamento numa casa que em parte integrava uma torre da muralha medieva (VASCONCELOS 1896, 218) - tem seduzido os investigadores para a interpretar como associada ao amuralhamento baixo-imperial da cidade, num processo que poderia ter sido coetâneo com o realizado em Conimbriga (ÉTINENNE et alii 1976, 118; ALARCÃo 1979, 25 e 37; 2008, 252-261; Mantas 1992, 510; De Man 2008, 14), levando mesmo a que se interpretasse a epígrafe como uma placa destinada a figurar encastrada na própria estrutura defensiva (ENCARNAÇÃo 1979, 176, n. 1; ALARCÃo 2008, 252). Na realidade, este suporte encontra-se, no topo e de ambos os lados, incompleto e picado nas partes superior e inferior da face principal, indiciando ter sido aí aplanada a molduragem que se afiguraria como base e capitel ao jeito de pedestal ${ }^{6}$, ainda que uma integração no contexto da muralha concite aceitação (DE MAN 2008, 260; 2009, 745).

O traçado da muralha romana de Aeminium e, concretamente, a sua leitura em função da fortificação medieval é matéria que continua sob discussão (DE MAN 2008, 260), mas há espaços da cidade relativamente bem definidos, pelo menos em termos de localização. E se o conhecimento que hoje existe sobre a estrutura urbana não chega a ser detalhado, é, todavia, possível uma caracterização genérica referente ao urbanismo e arquitectura. A origem da ocupação é pré-romana (Alarcão 1979, 25-26; Mantas 1992, 489-491; Alarcão 2008, 29; CARvalho et alii 2009, 70; Almeida et alii 2011; AlmeIDA et alii 2015), mas a escolha do assentamento para caput ciuitatis terá ditado um processo de renovação, urbanística e arquitectónica, que desembocou na abertura dos principais arruamentos e na construção de equipamentos

${ }^{6}$ A relação entre a altura e a largura, ainda que algo incompletas, é favorável a esta interpretação, devendo equacionar-se a possibilidade de o suporte ter sofrido seccionamento na sua espessura; no contexto do reaproveitamento da pedra na base duma cantareira em forma de armário cavado na parede, a face posterior é a que servia para assentar os potes de água, tendo estado a face gravada embebida e assente na parede de alvenaria (VASCONCELOS 1896, 218).

Conimbriga, 55 (2016) 57-89 
(Alarcão 1979, 23-28; Mantas 1992, 488-491; Alarcão 2008, 31). Entre estes contam-se um aqueduto, um teatro, quiçá um anfiteatro e um arco honorífico (MANTAS 1992, 502-510; AlarCão 2008, 37-57), sendo, porém, o forum a jogar papel fulcral no urbanismo de Aeminium, intersectando-se aí os dois principais eixos da cidade. O espaço forense remonta à época de Augusto, mas é ampliado (para sul e poente) em meados do século I, plausivelmente sob Cláudio, estruturando-se num modelo arquitectónico de basilica cum aede, a qual limitava a sua parte setentrional; nos restantes lados, a praça era fechada por cintura porticada corrida que teria, a nascente, comunicação com o exterior e se abriria para poente, tirando partido quer da topografia, quer da cenografia proporcionada pelo vale fluvial (CARVALHO 1998; ALARCÃO et alii 2009). No seu interior, uma aula albergaria os retratos imperiais conhecidos (de Lívia, Agripina Maior, Vespasiano e Trajano, e, quiçá, também de Augusto, Cláudio e Agripina Menor), possivelmente situada em posição oposta à basílica (AlARCÃo et alii 2009, 69-71), em correspondência com o desenvolvimento de um programa escultórico público associado ao culto imperial.

As escavações realizadas no criptopórtico em meados da década de 50 do século transacto exumaram, para além do material escultórico acima indicado, um pequeno altar (n. $\left.{ }^{\circ} 2\right)$, incompleto, dedicado precisamente ao genius basilicae (OleIro 1955-1956, 154-157). Esta categoria de genii associados a espaços arquitectónicos concretos não é claramente a mais representada quando comparada com a dos concernentes a indivíduos ou divindades, como desde cedo tem sido notado pelos historiadores da religião antiga ( $u$. g. TOUTAIN 1907, 462-464). Apontam, todavia, para o culto a um ente divino cujos contornos não se afiguram de simples apreensão, remetendo para a totalidade das características reunidas num ser ou entidade criada $(O C D, 608-609, s$. $u$. genius), como seja, neste caso concreto, a existência intrínseca ao edifício público especialmente dedicado à administração da justiça e a funções comerciais, funcionando como seu duplicado com características tutelares (Schilling 1979, 430). Cronologicamente, o altar é situável numa fase já madura da história do espaço forense, decerto não anterior aos finais do século II, mas a sua incompletude não permite conhecer a autoria da dedicatória, que bem poderia ter sido de algum notável engrenado na vida política da urbe, atendo à especificidade do estabelecimento basilical. A integração na ábside da basílica, onde se instalaria o tribunal, é hipótese fortemente atractiva. 
Escavações mais recentes realizadas no criptopórtico puseram ainda a descoberto uma pequena cabeça de calcário mitrítico, verosimilmente representando Vénus e datável do século I, que se encontra esgrafitada (n. $\left.{ }^{\circ} 15\right)$. A testa e faces encontram-se cobertas com vários alinhamentos de texto cuja leitura nem sempre resulta evidente, até porque alguns dos caracteres são quase imperceptíveis (CARVALHO 1998, 166-174). A sequência mais clara, quer pela dimensão dos caracteres quer pela profundidade da sua incisão, insere-se a meio da testa e parece corresponder a uma identificação individual de tipo peregrino: Capito Cinae. Se o primeiro elemento antroponímico é frequente nos meios provinciais peninsulares, quer como idiónimo, quer como cognome (Abascal 1994, 316-317; Grupo MÉrida 2003, 133-134), o segundo é claramente inusitado na Hispânia se o olharmos como grafia não geminada de Cinna (ABASCAL 1994, 328), cognome bem conhecido, nomeadamente associado aos L. Cornelii Cinnae, pai e filho, renomados aristocratas ligados a episódios famosos da história republicana, nomeadamente o massacre dos apoiantes de Sula e o assassinato de César (Bennett 1923; Syme 1939). O facto de, do ponto de vista semântico, ambos os nomes apontarem para particularidades físicas de conotação depreciativa ${ }^{7}$ levou a que se interpretassem como manifestação pejorativa relacionada com as características da obra escultórica, incisa em época em que esta teria perdido a sua importância e significado originais, resultando em expressão iconoclasta que indiciaria o declínio dos cultos clássicos em Aeminium durante os séculos III e IV (CARvalho 1998, 174). Considerar a utilização desta cabeça enquanto suporte de gravação como indício de perda de funcionalidade da mesma pode ser interpretação admissível, mas não definitiva. Afigura-se ainda mais difícil aceitar o carácter de mera expressão pejorativa, até do ponto de vista sintáctico, pelo que se torna mais simples a consideração de ambos os termos como antropónimos que compõem uma estrutura onomástica peregrina, quiçá fictícia. Esta percepção poderá sair reforçada pelo facto de se equacionar o seu acompanhamento pelo adjectivo uatius, que remete para uma deformação dos membros inferiores, em concreto para o chamado joelho em tesoura. Estar-se-ia, assim, em face

\footnotetext{
${ }^{7}$ Kajanto $(1965,106-107)$ associa o antropónimo Cinna ao nome latino primitivo cinna "careta, distorção facial", rara variante de cinnus. Por seu turno, Capito é também enquadrável numa categoria de nomes que remetem para particularidades físicas, no caso aludindo à cabeça desenvolvida (ibidem, 235).
}

Conimbriga, 55 (2016) 57-89 
de uma acção danosa anónima que resultou na depredação da escultura? A dimensão da cabeça sugere uma estátua relativamente pequena, com aproximadamente $1,30 \mathrm{~m}$, que já se sugeriu poder ter estado associada a uma fonte integrada no complexo forense (GONÇALVES 2007, 215), pelo que, num contexto de maior acessibilidade, a associação dos grafitos a pequenos actos de vandalismo não se nos afiguraria interpretação despropositada ${ }^{8}$. Pode aquela nomenclatura e a possibilidade de se encontrar o termo plebs em dativo a antecedê-la representar algum significado político? Evidentemente, os grafitos da peça implicam um mais aturado estudo que não podemos realizar neste contexto ${ }^{9}$, mas a ideia de vandalização da escultura afigura-se verosímil, não sendo certo que a sua descoberta no piso superior do criptopórtico corresponda a um enquadramento secundário decorrente de perda de funcionalidade por esse motivo, uma vez que os restantes elementos escultóricos que se conhecem associados ao forum foram igualmente exumados nesta construção que lhe serve de embasamento.

A ampliação do forum implicou também uma reformulação da malha urbana estruturante da arquitectura da cidade, como se comprova na área a poente deste espaço, onde, em época augustana, terá existido edifício relacionado com o tratamento de tecidos (Silva 2011), mas continua a ser limitado o conhecimento do urbanismo, sendo certo que a ortogonalidade dos arruamentos não terá sido regra (MANTAS 1992, 507-508; Alarcão 2008, 57-59). Noutros pontos da cidade romana, nomeadamente à frente da Sé Velha e no Pátio da Universidade, há registo da arquitectura doméstica da urbe (CORREIA 1946, 112-113; CAtarino e FiliPe 2003; FiliPe 2006, 345-350; AlarCão 2008, 63-64), mas todas as restantes inscrições por ora conhecidas se relacionam com pontos periféricos ${ }^{10}$.

${ }^{8}$ Construído de encosto à fachada ocidental do forum claudiano, um fontanário público integrava uma praceta contígua e, a nascente, no exterior do quadrante nordeste do mesmo espaço forense, associado ao cardus que antecedia a entrada principal, terá existido um arranjo urbanístico para o qual já foi sugerido, caso aquele eixo principal não tenha corrido imediatamente paralelo à fachada monumental, que pudesse ter contemplado um ajardinamento beneficiado com edificações relacionadas com a água (CARvalHo et alii 2009, 85-87).

${ }^{9}$ As observações ora realizadas resultam exclusivamente da análise da documentação publicada, sendo fundamental realizar novo estudo autóptico.

${ }^{10}$ Há, todavia, notícia do aparecimento de uma inscrição, supostamente romana,

Conimbriga, 55 (2016) 57-89 
As necrópoles associavam-se comummente aos eixos viários. É plausível ter existido uma necrópole ligada à via Olisipo-Bracara Augusta (Itin. Anton., 420, 8 a 422, 1) - que passava na área ribeirinha, não longe da zona portuária fluvial (MANTAS 1992, 500) - a situar por altura do troço final da rua da Sofia (ibidem, 500) ou quiçá na praça Velha (AlARCÃo 2008, 36-37), mas não se conhece evidência arqueológica ou epigráfica que se lhe associe. As inscrições funerárias de Aeminium surgiram todas entre a área do antigo castelo e a porta da Traição/Genicoca (Correia 1946, 13-23; Mantas 1992, 501; Alarcão 2008, 31 e 253), pelo que se relacionam com uma necrópole ligada a outro importante eixo viário que se desenvolvia acompanhando o aqueduto e conectava a cidade e a ciuitas cuja capital se associa a Bobadela (MANTAS 1992, 510; Alarcão 2008, 36). A necrópole situar-se-ia a ocidente da estrutura hidráulica de abastecimento da cidade, na área do Colégio de São Bento e Jardim Botânico (Correia 1946, 17).

$\mathrm{Na}$ ausência de registo arqueológico que elucide, no mínimo, sobre distintas linhas de estudo (tipos de sepultura, rituais...), pouco ou nada se poderá adiantar sobre a organização interna e social deste espaço dedicado aos mortos. A sua localização excêntrica relativamente ao núcleo urbano é a única garantia, contando-se para a sua caracterização apenas com os suportes dos epitáfios conhecidos, cuja tipologia permite imaginar uma diversidade grande de soluções referentes aos espaços funerários e a uma provável hierarquização interna relacionável com níveis socioeconómicos e culturais diferenciados. Decerto haveria um parcelamento que conformaria recintos dedicados à finalidade funerária nos quais se acomodariam alguns dos sepultamentos, como se poderá inferir da epigrafia, que, com certeza, conviveriam com núcleos menos formalizados.

Apenas desconhecemos o suporte de duas (n. ${ }^{\text {os }} 6$ e 11) das doze epígrafes funerárias associadas à necrópole. Entre os monumentos identificáveis, contam-se diversos tipos, com destaque para os cipos prismáticos de grandes dimensões (n. ${ }^{\text {os }} 4,5$ e 12), cupas (n. ${ }^{\text {os }} 3$ e 9) e caixas cinerárias (n. ${ }^{\text {os }} 8$ e 10), havendo registos únicos que incluem espécimes diferentes: uma ara (n. $\left.{ }^{\circ} 13\right)$, uma placa (n. ${ }^{\circ}$ 14) e um bloco arquitectónico (n. $\left.{ }^{\circ} 7\right)$.

a poente do forum, numa casa da rua das Fangas (actual rua de Fernandes Tomás), estando hoje perdida, sem que se conheça a sua natureza (Simões 1888, 19).

Conimbriga, 55 (2016) 57-89 
Os grandes cipos prismáticos de Aeminium são todos integráveis no século II. O cipo de Allia Vagellia Auita (n. ${ }^{\circ}$ 12), datável da segunda metade desta centúria, foi pensado por Le Roux e Fabre $(1971,127)$ com a função de pedestal que acolheria uma estátua, considerando que abre o epitáfio a expressão in honorem, a qual surge também em suporte idêntico de Conimbriga (FC II 60), apontando para uma produção relacionável com uma mesma oficina lapidária. Esta opção interpretativa veio a ser considerada para os monumentos de Conimbriga deste tipo, no qual se incluem duas referências a suportes desaparecidos $(F C$ II 57 e 71) e um pequeno fragmento ( $F C$ II 33), valorizando a existência de um dente de ferro ${ }^{11}$ no topo deste e de um entalhe no do primeiramente referido (ÉTIENNE et alii, 1976, 208-210). É certo que relativamente ao cipo de Allia Vagellia Auita não se conservam semelhantes indícios no topo (FERNANDES 1998-1999, 145), mas a sua conformação prismática, a mesma dos cipos de Cadius Carianus (n. $\left.{ }^{\circ} 4\right)$ e de G. Iulius Maternus (n. ${ }^{\circ} 5$ ), apela ao entendimento destes suportes como elementos que se completariam por bases e coroamentos volantes, estruturando, assim, se não pedestais, altares não monolíticos (BonNEville, 1984, 135). A mesma cronologia parece ter o altar de Vagellia Rufina iunior (n. $\left.{ }^{\circ} 13\right)$, olhando à qualidade do trabalho de gravação e à similitude paleográfica, pelo que remeterá, possivelmente, para a integração num recinto funerário familiar, destacando-se a diferença de escala entre os dois monumentos que teriam, num mesmo espaço, destaques verosimilmente distintos, lembrando, como à frente se verá, mãe e filha.

Dois outros monumentos salientam-se pela sua forma semicilíndrica e desenvolvimento horizontal. São claramente cupae solidae, isto é, líticas, que ostentam as inscrições funerárias no plano vertical duma das faces longas. Num dos casos, a inscrição que memoria um escravo de Allius Auitianus (n. ${ }^{\circ}$ 9) parece ocupar a toda a largura a parte superior desse plano sem se inscrever em espaço especialmente reservado para esse efeito, enquanto que noutro, o epitáfio, referente a um Aurelius Rufinus (n. ${ }^{\circ}$ 3), é acolhido em cartela rectangular rebaixada e delimitada por moldura que no mesmo plano surge centrada, ainda que as abreviaturas da consagração aos deuses Manes se encontrem deslocadas, nesse mesmo lado, para o topo arredondado. Este

${ }^{11}$ A propósito deste fragmento não se deixa de equacionar que em alternativa a uma estátua pudesse suportar um coroamento independente (ÉTIENNE et alii, 1976, 61).

Conimbriga, 55 (2016) 57-89 
particular tipo funerário marca a presença de uma sepultura que se desenvolve autonomamente sob o monólito (BonNEville 1981, 90), uma estruturação peculiar da moradia do defunto para a eternidade (ENCARNAÇÃo 2012, 438-440). A forma destas cupae, a lembrar claramente miniaturizações de mausoléus de abóbada semicircular, como os que se reconhecem em múltiplas necrópoles, inclusive em Roma ${ }^{12}$, é a este propósito significativa.

A caixa cinerária com repositório ovular de Iunia Peculiaris (n. ${ }^{\circ} 8$ ) é uma obra sóbria, apresentando, na face frontal, o epitáfio inserto em tabula ansata que é flanqueada por rebordos com quatro pares de rosas unidas por tronco ondeante, resultando num produto de grande requinte que levou Virgílio Correia $(1946,21)$ a ver aí o brilho longínquo do trabalho da pedra que a região veio a demonstrar ao longo da história. Em oposição, não tem qualquer ornamento o cinerarium de Pub[li]c[iu]s Geni[alis] (n. $\left.{ }^{\circ} 10\right)$, de receptáculo oblongo, ocupando a superfície vertical anterior apenas a inscrição. Faltam as tampas a ambos os monumentos, mas considerando, mesmo assim, que a sua dimensão regularia pela das cupae antes referidas, não descartamos que pudessem dispor-se a céu aberto, eventualmente associados a recintos funerários fechados, pois os cineraria, mormente os de dimensão reduzida, também poderiam utilizar-se integrados em edifícios funerários diversos (Di STEFANo Manzella 1987, 88); tão-pouco que pudessem, inclusive, representar um tipo distinto de cupa funerária, que, à semelhança das olisiponenses (CAMPOS 2012), fosse composto por duas partes, de que, neste caso, apenas teríamos a caixa paralelepipédica que se completaria com tampa de configuração semicilíndrica ${ }^{13}$.

À semelhança do epitáfio de Iunia Peculiaris, também o de Chrysis (n. ${ }^{\circ}$ ) está gravado num campo em tabula ansata, aproximando-se, na organização decorativa, do primeiro, mas divergindo na temática vegetal, pois as rosas foram substituídas por folhas de hera. As características deste suporte, todavia, fazem pensar na sua integração numa construção arquitectónica funerária, que já se sugeriu aproximar-se de um jazigo torriforme exemplificado pelo hornillo de Santa Catalina da

\footnotetext{
${ }^{12}$ Apenas a título meramente exemplificativo, podemos apontar a arquitectura da necrópole da uia Triumphalis (LiverANi e SPINOLA 2006).

${ }^{13}$ Refira-se que Fabre $(1973,124-125)$ considerou como cupa a peça com o epitáfio de Iunia Peculiaris (n. ${ }^{\circ}$ 8) e, inclusive, o suporte que tem o de Chrysis (n. ${ }^{\circ}$ 7), que corresponderá a um silhar.
}

Conimbriga, 55 (2016) 57-89 
necrópole oriental de Baelo Claudia (Correia 1946, 17), sendo este maciço nos seus dois primeiros corpos e com nicho no terceiro corpo, que dispunha de cobertura piramidal (Prados Martínez 2015, 85-86). Outra construção funerária seria possível, como um túmulo em forma de altar ou uma torre, considerando a documentação destes tipos no Ocidente hispânico (cf. SANTOS e CARVAlHo 2008; RibeIro 1982-1983, 333-340 e 446-449).

Para esta necrópole de Aeminium, há ainda a referir uma placa (n. ${ }^{\circ}$ 14) lembrando Modestus Modest $[i f$. $]$, calcária tal como os restantes monumentos, que terá estado associada a algum tipo de construção funerária mais desenvolvida.

Considerando os suportes elencados, será aceitável pensar que a paisagem funerária da cidade não diferiria substancialmente da de outros ambientes urbanos do litoral centro-lusitano no respeitante aos tipos de monumentos, como se constará pelo paralelo olisiponense (CAMPOS 2012, 465-467). E, também, que na mesma necrópole destas sepulturas de maior notoriedade, nas quais um epitáfio mantém viva a memória dos mais afortunados económica e socialmente, outras mais modestas e anónimas existiriam, sem mais que a terra amontoada. Mas as primeiras não se associam apenas a famílias que integraram o escol da urbe, juridicamente contrastadas pela posse da cidadania romana, já que igualmente aí se descortinam outros estatutos que abarcam não só a população livre, como também a servil ou com essa origem.

As inscrições funerárias de Aeminium são a únicas fontes que temos à mão para o estudo da sociedade local e a sua análise permite a identificação de 28 indivíduos pela sua denominação, ainda que nem sempre disponhamos das respectivas estruturas onomásticas comple$\operatorname{tas}^{14}$. Em termos de género, o número de homens supera o de mulheres na amostra, sendo exactamente o dobro (18 contra 9 , havendo um caso em que não é possível a distinção).

São os indivíduos com preeminência social, que, evidentemente, também decorre do seu estatuto jurídico, isto é, cidadãos romanos e seus libertos, os que maioritariamente surgem nas inscrições da necró-

${ }^{14}$ Contabilizamos três indivíduos que apenas indirectamente se identificam por via das filiações, os quais distribuímos entre o grupo dos cidadãos romanos e o dos peregrini, respectivamente Allius Auitianus (n. ${ }^{\circ}$ 9), [Al]buius (n. ${ }^{\circ}$ 11) e Modest [us] $\left(\mathrm{n} .{ }^{\circ} 14\right)$. Excluímos a estrutura onomástica peregrina associada à escultura do criptopórtico $\left(n .^{\circ} 15\right)$ pelas razões acima expostas.

Conimbriga, 55 (2016) 57-89 
pole $(71 \%)$. E nesta amostra, curiosamente, a percentagem de população servil (11\%) não se distancia grandemente da representação da peregrina (18\%), na qual também se considera a parcela correspondente a antigos escravos de peregrini.

Na realidade, apenas consta um liberto associado à componente peregrina da população, Paratus Modest [i] Modesti fili lib. (n. ${ }^{\circ}$ 14). Está referenciado como executor dos encargos referentes à sepultura do patrono, sendo mesmo possível que a sua libertação se tenha consumado com a morte deste e que os custos associados ao sepultamento tenham sido a compensação com ele acordada em vida (LE Roux e FABRE 1971, 123). Noutro epitáfio, é igualmente um liberto, Iulius Dexter, que se encarrega do memorial funerário do seu patrono (n. $\left.{ }^{\circ} 5\right)$, que the é destinado por duas filhas, Bouia Materna e Iulia Maxima. São estes os únicos casos em que se exprime declaradamente esse estatuto, pelo que as restantes identificações de liberti se sustentam na onomástica, considerando sobremodo a ocorrência de antroponímia de origem oriental, mas não só.

O epitáfio de Iunia Peculiaris (n. ${ }^{\circ}$ 8) é-lhe dedicado pelo filho, L. Iunius Rufus. Considerando a juventude da defunta, de apenas 22 anos, o facto de ambos partilharem o mesmo gentilício - evidenciando, assim, que o dedicante será plausivelmente um filho natural - e a especificidade adjectival do seu cognome na sua acepção mais directa ou etimológica, conjectura-se uma origem servil para ela (FABRE 1973, 125). A restituição Pub[li]c[iu]s Geni[alis $]$ referente ao nome do dedicante (conjuntamente com Modes[tus], seu filho) de um dos monumentos funerários incompletos (n. $\left.{ }^{\circ} 10\right)$ é valorável como denunciadora de um plausível liberto público, considerando o gentilício em causa e, inclusive, o carácter adjectival e semântica do cognome, apesar de este constar largamente entre a população livre (KAJANTO 1965, 260).

Destacam-se, em epitáfios distintos (n. ${ }^{\text {s }} 3$ e 6 , respectivamente), as nomenclaturas de Aurelius Musaeus e Albania Anchiale, pela integração de cognomes de origem grega (Solin 2003, 420 e 1443), tratando-se em ambas as situações de dedicantes que homenageiam familiares chegados: no primeiro caso, o filho, Aurelius Rufinus, a considerar cidadão romano de pleno direito e, no segundo, o marido, G. Kadius Melani[us] (?), cujo cognome restituído reflectirá a mesma origem linguística (ibidem, 750 e 1478). Esta última inscrição é particularmente interessante, uma vez que na homenagem intervirá, ao lado daquela mulher, o irmão do defunto, G. Kadius Saluianus, tendo, decerto, igual 
estatuto libertino e vinculação a um mesmo patrono, como aponta a partilha do gentilício ${ }^{15}$.

A importância comercial e portuária da cidade (MANTAS 1992, 500; Blot 2003, 210-211; Alarcão 2008, 25-27) terá sido, decerto, responsável pela projecção do meio libertino local, nomeadamente com ligações extrapeninsulares, como poderá acontecer neste último caso (LuCAS 1989, 175, 193 e 201).

Um epitáfio incompleto gravado sobre uma cupa (n. $\left.{ }^{\circ} 9\right)$ documenta indubitavelmente elementos da população servil: no caso, o escravo de um Allius Auitianus, representante de uma gens com outros testemunhos na cidade, lembrado pela companheira, $[A]$ moena, também ela seguramente de igual condição. A identificação apenas por um único nome, apesar de latino, aponta nesse sentido, sendo este mesmo critério que, da mesma forma, orienta para a interpretação de Chrysis (n. ${ }^{\circ}$ 7) também como escrava, mas com o reforço de esta ostentar um antropónimo de origem grega (Solin 2003, 1226 e 1481). Este encontra-se singularmente gravado num bloco do monumento que para si mandou fazer, uma atitude peculiar que levou à concitação dos mais diversos pensamentos relativamente ao modo de vida desta mulher sonhada pelo apelo da semântica áurica do seu nome (CORREIA 1946, 17; ENCARNAÇÃo 1979, 179-180).

Associados à população peregrina da cidade, apenas se contam dois epitáfios: um deles desaparecido e decerto bastante incompleto (n. $\left.{ }^{\circ} 11\right)$ identificaria, pelo menos, um indivíduo cujo idiónimo, contrariamente ao seu patronímico, [Al]buius, de raiz indígena (VALLEJO 2005, 123), não ousamos restituir; o outro, já o referimos anteriormente a propósito do liberto Paratus (n. ${ }^{\circ}$ 14) e recordava um Modestus Mo$\operatorname{dest}[i f$.], seu patrono, cujo nome (ABASCAL 1994, 430-431) espelha bem os caminhos da adopção de onomástica latina por parte da po-

${ }^{15} \mathrm{~A}$ possibilidade de o indivíduo que, conjuntamente com a viúva, participa nesta homenagem fúnebre ser o pai do defunto afigura-se-nos menos plausível, considerando a onomástica cognominal, quer do finado, quer da dedicante, denunciadora de provável estatuto libertino, já que tal apontaria no sentido de o marido falecido usufruir de um estatuto plenamente livre. A restituição do cognome do defunto com admissão da falta de letra no final parece-nos preferível - e justificável em face do número de caracteres das restantes linhas e do facto de o suporte estar incompleto acima dessa - à presunção de correspondência à forma Melas, atendendo à raridade deste nome na epigrafia ( $C I L$ $\mathrm{X}, 8148)$.

Conimbriga, 55 (2016) 57-89 
pulação local, ainda que mais bem evidenciados entre a que alcançou estatuto privilegiado.

A propósito da população servil ou com essa origem, já referimos algumas das gentes representadas na cidade, como a Allia, a Albania, a Aurelia e a Iunia. Mas outras, decerto até mais preeminentes na sociedade de Aeminium, de acordo com o investimento representado nos monumentos funerários que as denunciam, se notabilizam. Serão de destacar os Cadii, os Iulii e os Vagellii. A origem itálica dos Cadii e dos Vagellii tem sido posta em relevo (LuCAS 1989; FeRnANDEs 1998), bem como a sua aliança com famílias de extracção indígena.

A gens Cadia representada num dos cipos que se destacam por especial requinte decorativo e técnico (n. $\left.{ }^{\circ} 4\right)$ manifesta aí o seu laço com o substrato local, considerando a nomenclatura da mãe de $C a$ dius Carianus, falecido aos 21 anos, na qual sobressai um gentilício patronímico ou de origem patronímica, com clara raiz na onomástica autóctone (VALLEJO 2005, 119-121), associado a um cognome latino de forte expressão em meios nativos da Lusitânia (ABASCAL 1994, 292295; NAVARRo et alii 2003, 410), apontando para Alleicea Auita uma extracção indígena. Todavia, considerando que a inscrição que identifica dois Kadii de condição libertina (n. ${ }^{\circ}$ 6) será cronologicamente anterior, interrogamo-nos se estes eventualmente não representarão o advento dessa gens à cidade.

Independentemente da sua origem, autóctone ou alóctone com respeito à urbe, a ligação dos $I u l i i^{16}$ de Aeminium com o substrato indígena acaba por se evidenciar, nomeadamente pela identificação de uma das filhas de G. Iulius Maternus que não apresenta o mesmo gentilício. O monumento que o memoria (n. $\left.{ }^{\circ} 5\right)$, também um notável cipo prismático com afinidades com o de Cadius Carianus, é mandado fazer por Bouia Materna e Iulia Maxima ao pai, mas apenas a segunda se afigura filha legítima, sendo provável que a primeira tenha nascido antes da concretização de uma união legal com a progenitora, recebendo um cognome decalcado do paterno e o gentilício desta, cuja homofonia relativamente à onomástica indígena (VALLEJo 2005, 215) sugere vinculação à população local, algo que se afigura coerente com o que vislumbrámos com os Cadii e que também se manifesta com os Vagellii.

Esta gens está documentada em dois epitáfios (n. ${ }^{\circ} 12$ e 13), tendo

${ }^{16}$ Este é o gentilício mais difundido na Lusitânia (GRUPO MÉRIDA 2003, 407).

Conimbriga, 55 (2016) 57-89 
eles relação estreita, pois ambos são fruto da intervenção dos mesmos dedicantes. As defuntas são mãe e filha, Allia Vagellia Auita e Vagellia Rufina iunior, tendo recebido cada uma seu monumento: um cipo prismático idêntico aos apontados anteriormente e uma ara, como acima se aludiu. Os dedicantes são, em ambos os casos, G. Allius Auitus, pai e avô, e Q. Siluanius Siluanus, marido e pai, respectivamente. O primeiro associa-se a família autóctone enraizada em ambas as margens do Mondego, pois também em Conimbriga se identificam Allii cuja pujança terá decorrido da posse de propriedade fundiária e da produção oleira (ÉTIENNE et alii 1976, 67; ENCARNAÇÃo 1979, 178; FERNANDES 1998, 271-274). Mas também Q. Siluanius Siluanus terá extracção local, olhando à sua onomástica e, sobretudo, à constatação de que o seu gentilício é decalcado do cognome (Fernandes 1998, 263; Le Roux 2010, 198), um antropónimo que, para além de uma significativa representação no Ocidente lusitano (GRUPO MÉRIDA 2003, 304-305), tem distintas ocorrências na vizinha Conimbriga ( $F C$ II 65 e 412). Todavia, o gentilício Vagellius, circunscrito, no contexto hispânico, a Aeminium, tem relação comprovada com a península itálica (FERNANDES 1998, 274), sendo inclusive considerado como fóssil onomástico no quadro provincial (NAVARRo et alii 2003, 409). O relevo desta gens no contexto local parece evidenciar-se de forma iniludível: desde logo pela circunstância de a nomenclatura de Allia Vagellia Auita incorporar ao lado do gentilício paterno essoutro que remete para a família da mãe, particularidade onomástica que é ainda reforçada pelo facto de à sua filha ter sido dado o nome de Vagellia Rufina iunior que, logicamente, parece evocar a avó. À primeira vista, este aspecto contrasta com a afirmação da paternidade por parte de $Q$. Siluanius Siluanus, pelo que já se entendeu que denotaria que Allia Vagellia Auita não se encontraria in manu do marido, mas sob a potestas do progenitor e que este, com a plausível morte da filha no contexto do parto, teria tomado a opção de dar à neta, supostamente falecida pouco depois, o nome da esposa, decisão que significaria, ainda, a assunção de um desnivelamento social importante com respeito ao genro (Le Roux e FABRE 1971, 127-129). O argumento jurídico vê-se, todavia, enfraquecido pelo facto de, mesmo no casamento sem manu, os filhos ficarem na potestas paterna (Evans-GruBbs 2002, 21), pelo que será de privilegiar o entendimento de que o desnivelamento social, quiçá radicado numa naturalização recente do pai, eventualmente conseguida pela via do exercício das magistraturas locais no quadro do ius Latii, poderá ter ditado que, nesta manifesta- 
ção epigráfica concreta - na qual se opta por um monumento também mais contido e a exigir alguma parcimónia quanto à mensagem, como revela a opção duonominal para os nomes do avô e do pai -, se tivesse preferido registar uma nomenclatura reduzida na qual se salientam os elementos onomásticos que remetem para os pergaminhos familiares associados à linhagem da avó, a gens Vagellia, plausivelmente de largo renome na cidade ${ }^{17}$.

Será de realçar que uma das peculiaridades associadas à epigrafia funerária de Aeminium é a elegância da decoração quando esta surge como linguagem complementar aos epitáfios propriamente ditos, isto é, como parte integrante dos monumentos a permitir diversos níveis de leitura (SUSINI 1982, 54).

Referimos a decoração de carácter vegetalista associada a cartelas em forma de tabula ansata em dois dos suportes (n.os 7 e 8), mas é nos cipos paralelepipédicos, que vimos associados às famílias dos Cadii, Iulii e Vagellii, que uma linguagem plástica muito própria se exibe e que não tem passado despercebida aos investigadores (LE Roux e FABRE 1971, 130; ENCARNAÇÃo 1979, 178-179; FERNANDES 1998, 266).

Para além da técnica atilada na execução dos tituli enquadrados em espaços delimitados por sóbria molduragem, estes suportes apresentam, lateralmente, representações singulares de objectos concretos cuja leitura releva para a linguagem que o leitor/transeunte que cruzava a necrópole era incitado a descodificar. Um traço comum a todos eles é a representação de instrumenta scriptoria, mas apenas no referente ao de Cadius Carianus (n. ${ }^{\circ}$ 4) são exclusivos: de um lado, díptico a par de estojo com estiletes; do outro, volume aberto a par de estojo com cálamos. No suporte do epitáfio de G. Iulius Maternus (n. ${ }^{\circ}$ 5) é-lhes reservada apenas uma face, na qual pontuam, de cima para baixo, um volume aberto, um estojo com estiletes e um díptico, enquanto que a outra recebe representações de objectos rituais não desusados nos monumentos funerários, que, de cima para baixo, são uma colher de cabo longo, uma pátera e um jarro. No cipo paralelepipédico de Allia Vagellia Auita (n. $\left.{ }^{\circ} 12\right)$, essa presença resume-se à representação de um díptico, que ocupa posição central numa das faces, entre a figuração de uma grinal-

${ }^{17}$ Plausivelmente o nome completo remeterá para a mesma estratégia onomástica que de forma explícita ilustra o nome da mãe, com duplo cognome em que o primeiro corresponde a forma gentilícia que alarga a onomástica familiar.

Conimbriga, 55 (2016) 57-89 
da e a de uma edícula com cátedra e banco no seu interior; na oposta, representam-se, de cima para baixo, um espelho, uma edícula contendo um cofre, um cesto e duas rocas, ladeada por dois fusos, e uma concha.

Ainda que, em algumas situações, a figuração de utensílios possa ter uma ligação directa com a profissão dos defuntos, noutras ela não revestirá um significado tão estrito, mas, antes, actua como símbolo (ENCARNAÇão e LEAL 1996, 176; BuONOPANe 2013). A reiterada reprodução de instrumenta scriptoria nos monumentos de Aeminium ${ }^{18}$ tem decerto o valor simbólico de um ideal de cultura e instrução (ENCARNAÇÃo 1979,178$)$ que pretendia significar a dignidade e superioridade social dos defuntos (VeYne 1989, 33). E esse registo metafórico sai reforçado quando essas representações se enlaçam com outras, quer de maior pendor funerário, como os objectos rituais (simpulum, patera e urceus), quer afins, como a cátedra, ou quer, ainda, com as que remetem para o recato feminino, como ocorre na gramática decorativa mais profusa do último exemplo, do qual transpira uma leitura moral associada à sabedoria e cultura, à beleza sóbria e discreta, à pudicícia e à reserva da mulher que bem metaforiza a alusão ao lanificium como ideal matronal (GOUREVITCH e RAEPSAET-CHARLIER 2005, 87) ${ }^{19}$.

Representa esta iconografia, numa leitura estritamente ideológica, adesão manifesta aos ideais da cultura greco-romana por parte dos seus utilizadores, os grupos familiares que memoriam os seus entes queridos, neste caso representantes do escol urbano.

A epigrafia da cidade romana de Aeminium que hoje temos possibilidade de contemplar, apesar de não muito abundante, permite-nos, como fomos vendo, alicerçá-la no cenário histórico da urbe que, pela via da Arqueologia, se vai delineando, reforçando-o pelo esboço socioeconómico, cultural e ideológico que ajuda a traçar.

Em suma, a leitura total dos diferentes suportes epigráficos e da sua inserção no espaço urbano a par da análise dos conteúdos escritos e da iconografia proporcionam mais algumas achegas para a história dessa Aeminium cuja localização sobranceira ao Munda é também hoje indiscutível por esta via.

${ }^{18}$ Também em Conimbriga há registo de dois monumentos funerários idênticos e com este tipo de decoração ( $F C$ II 57 e 71).

${ }^{19}$ A iconografia destes suportes, pela sua importância específica e também pelas limitações inerentes ao presente artigo, será objecto de análise mais desenvolvida em subsequente trabalho.

Conimbriga, 55 (2016) 57-89 


\section{APÊNDICE: inscrições romanas de Aeminium}

[A apresentação de cada uma das epígrafes inclui: nota referente ao achado; menção ao tipo de suporte, às suas dimensões gerais e natureza material; proposta de datação; leitura do texto; e referências bibliográficas.]

\section{Homenagem da ciuitas Aeminiensis a Constâncio Cloro.}

Casa particular que integrava a torre de Precónio (demolição em 1888). Pedestal (?); [130]x[47]x[13]; calcário. 305-306.

ẠT AVGMENTVM / [R|ẸI · PVB(blicae) · NATO [DI]/LECTOQVE · PRIṆ/[C|IPI · D(omino) N(ostro) FLAVIO / $\overline{\mathrm{VA} L}$ (erio) · CONSTANTIO / [PI|O FELICI INVICTO $\cdot$ AV $/[G] V S T O \cdot P O N T($ ifici) $\cdot$ MAX̣(imo) / [T]R R IB(unicia) $\cdot$ POT(estate) · $\mathrm{P}($ atri $) \cdot \mathrm{P}($ atriae $) \cdot \mathrm{PRO} \overline{\mathrm{CO}} \mathrm{N}($ suli $) /$ [CIV|ITTAS AEMINIENS[IS]

FigueIREDo 1888a e 1888c; CIL II 5239 (e add., 1031); VASCONCELOS 1896; CASTro 1930; MMCSAA, 9, n. ${ }^{\circ}$ 14; Correia 1946, 27-29; RoDRIGUES 1959-1960, 113-114, n. ${ }^{\circ}$ 1; ILER 1218 e 1236; ENCARNAÇÃO 1979, 173-176; HenRIQues 1993, 129-130, n. ${ }^{\circ} 12$.

\section{2. Árula dedicada ao Génio da basílica.}

Criptopórtico (obras de 1955-1956). Árula; [18,2]x11,2x?; calcário. 175-250.

GIINIO / BASELE/C̣AE (!) Ș/|ACRVM?| / [---

OLEIRO 1955-1956, 156; AE 1959, 112; HAE 1558; ILER 549; Le RouX e FABRE 1971, 118-121, n..$^{\circ}$;; AE 1972, 243; ENCARNAÇÃo 1979, 176; RAP 257; HENRIQUES 1993, 123-124, n. ${ }^{\circ} 1$.

\section{Epitáfio de Aurelius Rufinus.}

Alicerce do terreiro do castelo (demolição em 1773). Cupa; 54x75x31; calcário. 131-200.

D(is) ¿े M(anibus) ¿ S(acrum) / AVRELIO - RVFINO / ANN(orum) ¿ XVII / AVRELIVS $\cdot$ MVSAEVS / FILIO $\cdot$ PIISSI $\{\cdot\}$ MO $\cdot$ F(aciendum) $\cdot$ C(urauit)

CIL II 368 (e Suppl., 815); Campos 1874-1875, 232, n. ${ }^{\circ} 3$ = 1877, 6, Conimbriga, 55 (2016) 57-89 
n. ${ }^{\circ} 3$; Figueiredo 1884, 81, n. ${ }^{\circ} 3$; Simões $1879,14=1888,17$; $M M C$ SAA, 5, n. ${ }^{\circ} 8$; Correia 1946, 15-16; Rodrigues 1959-1960, 117-118, n. ${ }^{\circ}$; ILER 4174; ENCARNAÇÃo 1979, 176; HenRIQUes 1993, 124, n. ${ }^{\circ} 2$.

\section{Epitáfio de Cadius Carianus.}

Lanço de muralha junto ao Arco da Traição (demolição em 1878). Cipo prismático; 106x46x33; calcário. 131-200.

D(is) ¿) M(anibus) ¿े S(acrum) / CADIO / CARIANO / ANN(orum) ¿ XXI / ALLEICEA / AVITA MATER / FILIO : FAC(iendum) · C(urauit) / DIC · ROGO QVI ȚRANSIS ȘIT · TIBI · / TERRA · LEVIS

CIL II 5241; CAMPOS 1880-1881, 198, n. ${ }^{\circ} 16=1883,5$, n. ${ }^{\circ} 16$; FigueIreDO 1884, 82, n. ${ }^{\circ}$ 6; Simões 1879, $15=1888,19$; FigueIREdo 1888d; $M M$ CSAA, 6, n. ${ }^{\circ}$ 9; CORREIA 1946, 20-21; ROdRIGUES 1959-1960, 121, n. ${ }^{\circ} 12$; ILER 3793; ENCARNAÇÃO 1979, 178-179; LUCAS 1989, 175-178, n. ${ }^{\circ}$ 2; HenRiQues 1993, 124-125, n. ${ }^{\circ} 3$; EnCARnaÇão e Leal 1996, 178, n. ${ }^{\circ} 4$.

\section{Epitáfio de G. Iulius Maternus.}

Junto ao castelo, nas ruínas da couraça de Lisboa (1774). Cipo prismático; 117x49x36; calcário. 101-200.

D(is) ¿ M(anibus) ¿ S(acrum) / G(aii) · IVLI / MATERNI / ANN(orum) • LXIIII / BOVIA · MA/TERNA · ET / IVLIA · MA/XIMA · PATRI / PIISSIMO / F(aciendum) C(urauerunt) / CVRANTE / IVLIO DEX/TRO LIBER/TO OB MERI/TA · PATRONI

CIL II 378 (e Suppl., 815); CAmpos 1874-1875, 234-235, n. ${ }^{\circ} 5=1877$, 7-9 n. $^{\circ}$ 5; FigueIredo 1884, 81, n. ${ }^{\circ}$ 4; Figueiredo 1886, 257-258; SIMÕES 1879, 14-15 = 1888, 18-19; MMCSAA, 5, n. ${ }^{\circ} 6$; CORREIA 1946, 19-20; Rodrigues 1959-1960, 120-121, n. ${ }^{\circ} 11$; ILER 3949; ENCARNAÇÃo 1979, 178; HeNRIQUES 1993, 125-126, n. ${ }^{\circ}$ 4; ENCARNAÇÃO e LEAL 1996,178, n. $^{\circ} 3$.

\section{Epitáfio de G. Kadius Melanius (?).}

Muralha do castelo (século XVI?). Calcário (?). 75-150.

Conimbriga, 55 (2016) 57-89 
---] / G(aio) · KIA|DIO · 'MI'ILANI|Ol?/ ANN(orum) · XXXVI / G(aius) ·

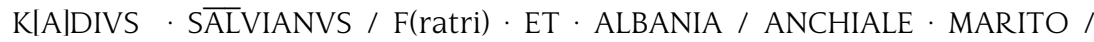
$\mathrm{F}$ (aciendum) C(urauerunt) $\cdot \mathrm{S}(\mathrm{it}) \cdot \mathrm{T}(\mathrm{ibi}) \cdot \mathrm{T}($ erra $) \cdot \mathrm{L}$ (euis)

CIL II 380; ILER 4872; ENCARNAÇÃO 1979, 178; LuCAS 1989, 173-175, n. ${ }^{\circ} 1$; HeNRIQUES 1993,126, n. $^{\circ} 5$.

\section{Epitáfio de Chrisys.}

Alicerce do terreiro do castelo (demolição em 1773). Bloco arquitectónico; 48x[81]x43; calcário. 75-150.

CHRISYS SIBI / POSVIT

CIL II 374 (e Suppl., 815); CAMPos 1874-1875, 229, n. ${ }^{\circ} 1=1877,5$, n. $^{\circ} 1$; FigueIredo 1884, 80, n. ${ }^{\circ} 1$; SiMÕes 1879, $14=1888,17$; $M M C$ SAA, 2, n. ${ }^{\circ}$ 9; CORREIA 1946, 13-15; Rodrigues 1959-1960, 121-122, n. $^{\circ}$ 13; ILER 3681; ENCARNAÇÃo 1979, 176 e 179-180; HENRIQUES $1993,126-127$, n. $^{\circ} 6$.

\section{Epitáfio de Iunia Peculiaris.}

Lanço de muralha junto ao Arco da Traição (demolição em 1878). Caixa cinerária; 35x77x43; calcário. 75-150.

IVNIAE PECVLIARI / ANN(orum) · XXII / L(ucius) · IVNIVS RVFVS / MATRI · $\mathrm{F}$ (aciendum) $\cdot \mathrm{C}$ (urauit)

CIL II 5242; CAMPos 1880-1881, 199, n. ${ }^{\circ} 17=1883,6$, n. ${ }^{\circ} 17$; FigUEIREDO 1884, 82-83, n. ${ }^{\circ}$ 7; Simões 1879, $15=1888,19 ;$ MMCSAA, 5, n. $^{\circ}$ 2; CoRreia 1946, 21-22; Rodrigues 1959-1960, 117, n. ${ }^{\circ}$ 6; ILER 3995; ENCARNAÇÃo 1979, 178; HeNRIQUES 1993, 127, n. ${ }^{\circ} 7$.

\section{Epitáfio de um escravo de Allius Auitianus.}

Muralha, ao arco da Traição (1941). Cupa; 59x[56]x30; calcário. 101200 .

[---|NI · ALLI · AVITIANI ¿ SER/IVO A]ṂOENA VXOR / [F(aciendum)] C(urauit) 
MMCSAA, 6, n. ${ }^{\circ}$ 13; Rodrigues 1959-1960, 124, n. ${ }^{\circ}$ 18; ILER 5095; HeNRIQUeS 1993, 127-128, n. ${ }^{\circ}$ 8; Fernandes 1998-1999, 182, n. 212.

\section{Epitáfio da esposa de Publicius Genialis.}

Alicerce do terreiro do castelo (demolição em 1773). Caixa cinerária; [41]x83x50; calcário. 101-200.

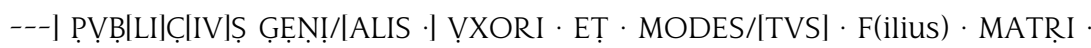
$\mathrm{F}($ aciendum $) \cdot \mathrm{C}($ urauerunt) $/ \mathrm{S}(\mathrm{it}) \cdot \mathrm{T}(\mathrm{ibi}) \cdot \mathrm{T}($ erra $) \cdot \mathrm{L}($ euis $)$

CIL II 394 (e Suppl., 815, 1030); Campos 1874-1875, 230-231, n. ${ }^{\circ} 2$ $=1877,5-6$, n. $^{\circ}$ 2; FigueIredo 1884, 81, n. ${ }^{\circ} 2$; Figueiredo 1888b; SiMÕES 1879, $14=1888,17$; MMCSAA, 2, n. ${ }^{\circ}$ 14; CORREIA 1946, 15; Rodrigues 1959-1960, 122-123, n. ${ }^{\circ} 15$; HenRIQues 1993, 128, n. ${ }^{\circ} 9$.

\section{Epitáfio de defuntos desconhecidos.}

Alicerce do terreiro do castelo (demolição em 1773). Calcário (?). $1-100$.

---| / ALAI--- AL//BVI F(ili---) |---| / I(c) (!) S S(iti) · S(unt)

CAmpos 1874-1875, 232-233, n. 2 = 1877, 6-7, n. 2; Figueiredo 1884, 81, n. 1; Simões 1879, 14 = 1888, 17; CIL II 5244; HenriQues 1993, $129,{ }^{\circ}{ }^{\circ} 11$.

\section{Epitáfio de Allia Vagellia Auita.}

Muralha, sob a actual Faculdade de Ciências (década de 60 do século XX). Cipo prismático; 97,6x63,7x49,7; calcário. 151-200.

[D(is) @] M(anibus) ¿ S(acrum) / [IN] HONOREM / MEMMORIAE ALLI $\overline{A E}$ / VAGELLIAE AVITAE / ANN(orum) Q XXVI / G · ALLIVS · AVITVS / PATER · FILIAE / PIISSIMAE · ET · / Q(uintus) - SILVANIVS / SILVANVS · MARITVS / VXORI / [I]ṆDVLGENTISSIMAE / [ET] MERITISSIMAE / F(aciendum) ?? Ç(urauerunt)

Le Roux e Fabre 1971, 126-130, n. ${ }^{\circ}$ 5; AE 1972, 241; ENCARNaÇão Conimbriga, 55 (2016) 57-89 
1979, 178; Henriques 1993, 130, n. ${ }^{\circ}$ 13; EnCARnaÇÃo e Leal 1996, 178, n. ${ }^{\circ}$ 5; Fernandes 1998, 262-266, n. ${ }^{\circ}$ 1; HEp 9, 740; Fernandes 1998-1999, 143, n. 107.

\section{Epitáfio de Vagellia Rufina iunior.}

Muralha, sob o actual Departamento de Matemática da Faculdade de Ciências (década de 60 do século XX). Ara; 57x24x20,5; calcário. 151200.

D(is) ¿े M(anibus) ¿े S(acrum) / VAGELLIAE / RVFINAE / IVNIORI · ALLIVS / AVITVS $\cdot$ AV(u)S $\cdot$ / ET $\cdot$ SILVANIVS / SILVANVS / PATER / F(aciendum) C(urauerunt)

Le Roux e FABre 1971, 124-126, n. ${ }^{\circ}$ 4; $A E$ 1972, 240; ENCARNAÇ̃̃o 1979, 178; Henriques 1993, 130-131, n. ${ }^{\circ}$ 14; Fernandes 1998, 266268, n. ${ }^{\circ} 2$; HEp 9, 741; FerNANDES 1998-1999, 182, n. 209.

\section{Epitáfio de Modestus Modesti f.}

Muralha, sob o actual Departamento de Matemática da Faculdade de Ciências (década de 60 do século XX). Placa; 46,1x 108,5×24,5; calcário. $75-150$.

MODESTO MỌDEST|I F(ilio)] / PARATVS MODESṬ|II / MODESTI - FILI LIB(ertus) / EX · TESTAMENTO $\cdot$ F(aciendum) $\cdot$ C (urauit)

Le Roux e Fabre 1971, 121-124, n. ${ }^{\circ} 3$; AE 1972, 242; HenriQues 1993, 131, n. $^{\circ} 15$.

\section{Cabeça de Vénus esgrafitada.}

Criptopórtico (1996/1997). Escultura; 19x17x23; calcário. 1-100.

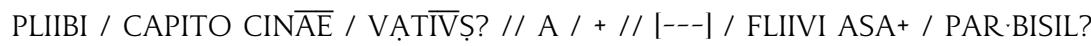
|---| TA / TIS+ TSI?LIBB ++ / |---|

Carvalho 1998, 166-174; HEp 8, 599; Gonçalves 2007, 213-215, n. ${ }^{\circ} 81$.

Conimbriga, 55 (2016) 57-89 


\section{BIBLIOGRAFIA}

Abascal Palazón, J. M. (1994), Los nombres personales en las inscripciones latinas de Hispania, Murcia-[Madrid]: Universidad, Secretariado de Publicaciones-Universidad Complutense.

Alarcão, J. (1979), As origens de Coimbra, in Actas das I Jornadas do Grupo de Arte e Arqueologia do Centro, Coimbra: Grupo de Arqueologia e Arte do Centro, 2340.

AlarCão, J. (1990), Identificação das cidades da Lusitânia portuguesa e dos seus territórios, in Les Villes de Lusitanie romaine: hiérarchies et territoires (Table ronde internationale du CNRS - Talence, 8-9 décembre 1988), Paris: Éd. du Centre Nacional de la Recherche Scientifique (Collection de la Maison des pays ibériques; 42), 21-34.

Alarcão, J. (2008), Coimbra: a montagem do cenário urbano, Coimbra: Imprensa da Universidade de Coimbra.

Alarcão, J., André, P., Barrelas, P., Carvalho, P. C., Santos, F. P., Silva, R. (2009), $O$ forum de Aeminium: a busca do desenho original, Coimbra: Museu Machado de Castro-Edifer.

Almeida, S. O., Nóbrega, J. R., Vilaça, R., Silva, R. C. (2011), Cerâmica da II Idade do Ferro de Aeminium - R. Fernandes Tomás 72/74 (Coimbra, Portugal), Conimbriga, 50, 33-57.

Almeida, S. O., Silva, R. C., VilaçA, R. (2015), Testemunhos da ocupação pré-romana no forum de Aeminium (Coimbra, Portugal), Antrope, 3, 39-63.

Andreu Pintado, J. (2004), Edictum, Municipium y Lex: Hispania en época Flavia (69-96 d. C.), Oxford: Archaeopress.

Année Épigraphique, L', Paris: CNRS; Université de Paris I (= AE ).

Bennett, H. (1923), Cinna and His Times: a Critical and Interpretive Study of Roman History During the Period 87-84 BC, Menasha, WI: The Collegiate Press.

Bejarano, V. (1987), Fontes Hispaniae Antiquae VII: Hispania Antigua, según Pomponio Mela, Plinio el Viejo y Claudio Ptolomeu, Barcelona: Instituto de Arqueología y Prehistoria.

BLot, M. L. P. (2003), Os portos na origem dos centros urbanos: contributo para a arqueologia das cidades marítimas e flúvio-marítimas em Portugal, Lisboa: Instituto Português de Arqueologia.

Bonnelille, J.-N. (1981), Les cupae de Barcelone: les origines du type monumental, Mélanges de la Casa de Velázquez, 17, 5-38.

Bonnelille, J.-N. (1984), Le support monumental des inscriptions: terminologie et analyse, in Épigraphie hispanique: problèmes de méthode et d'édition (Actes de la Table Ronde Internacional du C. N. R. S. organisée à l'Université de Bordeaux III les 8-9-10 décembre 1981), Paris: De Boccard, 117-152.

Bost, J.-P., FABre, G. (1983), Quelques problèmes d'histoire dans deux cités de l'Aquitaine méridionale à l'époque gallo-romaine, Aquitania, 1, 25-36.

Buonopane, A. (2013), Le raffigurazione di utensili nelle iscrizione funerarie: da

Conimbriga, 55 (2016) 57-89 
immagini parlanti a simbolo, Sylloge Epigraphica Barcinonensis, 11, 73-82.

Caballos Rufino, A. (2001), Latinidad y municipalización de Hispania bajo los Flavios: estatuto y normativa, Mainake, 23, 101-119.

CAmpos, J. C. A. (1874-1875), Seç̧ão de Archeologia: catalogo dos objectos existentes na collecção de Archeologia do Instituto de Coimbra, O Instituto, 20, 229-240.

Campos, J. C. A. (1877), Catálogo dos objectos existentes no Museu de Arqueologia do Instituto de Coimbra: 1873-1877, Coimbra: Impensa Litteraria.

CAmpos, J. C. A. (1880-1881), Secção de Archeologia: catalogo dos objectos existentes no Museu de Archeologia do Instituto de Coimbra: supplemento comprehendendo os objectos offerecidos e depositados desde abril de 1877, O Instituto, 28, 192-200.

Campos, J. C. A. (1883), Catalogo dos objectos existentes no Museu de Archeologia do Instituto de Coimbra a cargo da Secção de Archeologia do mesmo Instituto: supplemento $1^{\circ}$ : 1877-1883. Coimbra: Imprensa da Universidade.

CAmpos, R. (2012), As cupae de Olisipo e do ager Olisiponensis, in Andreu Pintado, J. (ed.), Las cupae hispanas: origen, difusión, uso, tipología, Tudela: UNED-Fundación Uncastillo, 449-474.

Carvalho, P. C. (1993), Fragmentos de inscrições romanas do Museu Nacional Machado de Castro, Coimbra: Museu Machado de Castro.

Carvalho, P. C. (1998), $O$ forum de Aeminium, Coimbra: Instituto Português de Museus.

Carvalho, P. C., Matias, D., Almeida, A., Ribeiro, C., Santos, F., Silva, R. (2009), Caminhando em redor do forum de Aeminium (Coimbra, Portugal), in Nogales Basarrate, T. (ed.), Ciudad y foro en Lusitania Romana, Mérida: MNAR, 69-88.

Castro, A. M. S. (1930), Aeminium, Arte e Arqueologia, 1:2, 65-67.

Catarino, H., Filipe, S. (2003), A História tal qual se faz no Pátio da Universidade de Coimbra: apresentação sumária dos vestígios de época romana, in Encarnação, J. d' (coord.), A História tal qual se faz, Lisboa: Colibri-Faculdade de Letras da Universidae de Coimbra, 49-63.

Correia, V. (1946), Obras, I: Coimbra, Coimbra: Universidade.

Cuntz, O. (ed.) (1990), Itineraria Antonini Augusti et Burdigalense, Stuttgart: G. B. Teubner.

De Man, A. (2008), Defesas urbanas tardias da Lusitânia, Porto: FLUP (Tese de Doutoramento policopiada).

De Man, A. (2009), Late Urban Defences of the Lower Mondego: the cases of $A e-$ minium and Conimbriga, in Morillo Cerdán, Á., Hanel, N., Martín Hernández, E. (eds.), Limes XX: estudios sobre la frontera romana (Roman frontier studies), Madrid: Consejo Superior de Investigaciones Científicas-Polifemo, 741-748.

Di Stefano Manzella, I. (1987), Mestiere di epigrafista: guida alla schedatura del materiale epigrafico lapideo, Roma: Quasar.

Dondin-Payre, M. (1997), Réexamen des magistratures municipales des Gaules d'après l'épigraphie, Cahiers du Centre Gustave Glotz, 8, 285-300.

ENCARNAÇÃo, J. d' (1979), Notas sobre a epigrafia romana de Coimbra, in Actas das

Conimbriga, 55 (2016) 57-89 
I Jornadas do Grupo de Arte e Arqueologia do Centro, Coimbra: Grupo de Arqueologia e Arte do Centro, 171-180.

Encarnação, J. d' (2012), A propósito das cupae do conuentus Pacensis, in Andreu Pintado, J. (ed.), Las cupae hispanas: origen, difusión, uso, tipología, Tudela: UNED-Fundación Uncastillo, 437-450.

EnCARnaÇÃo, J. d', LEAL, C. C. (1996), Technique et métiers dans l'épigraphie romaine de l'occident hispanique, in Khanoussi, M., Ruggeri, P., Vismara, C. (eds.), L'Africa Romana XI: atti dell'XI convegno di studio (Cartagine, 15-18 dicembre 1994), Ozieri: Il Torchietto, 175-181.

ÉtIenne, R., FABre, G., LÉvÊQue, P. e M. (1976), Épigraphie et sculpture, Paris: De Boccard, 1976 (Fouilles de Conimbriga; 2) (=FC II).

Evans-Grubbs, J. (2002), Women and Law in the Roman Empire: a Sourcebook on Marriage, Divorce and Widowhood, London-New York: Routledge.

FABre, G. (1973), Un affranchi impérial à Conimbriga: P. Aelius Ianuarius (A. E., 1954, $\mathrm{n}^{\circ}$ 86), Revue des Études Anciennes, 75, 111-125.

Fernandes, L. S. (1998), Os Vagellii de Aeminium, Máthesis, 7, 261-290.

FERNANDES, L. S. (1998-1999), A presença da mulher na epigrafia romana do conuentus Scallabitanus, Portugalia, nova série, 19-20, 129-228.

Figueiredo, A. C. B. (1884), Oppida restituta, as cidades mortas de Portugal: Eminio, Boletim da Sociedade de Geographia de Lisboa, $5^{\text {a }}$ série, 2, 67-92.

Figueiredo, A. C. B. (1886), Coimbra Antiga e Moderna, Lisboa: Livraria Ferreira.

Figueiredo, A. C. B. (1888a), Um monumento de Aeminium, Revista Archeologica e Historica, 2, 66-68.

Figueiredo, A. C. B. (1888b), Miscellanea: I - Inscripção de Aeminium, Revista Archeologica e Historica, 2, 109-110.

FigueIredo, A. C. B. (1888c), Um monumento de Aeminium (rectificação), Revista Archeologica e Historica, 2, 125.

Figueiredo, A. C. B. (1888d), Miscellanea: I - Inscripção de Aeminium, Revista Archeologica e Historica, 2, 126.

FILIPE, S. (2006), Arqueologia urbana em Coimbra: um testemunho na Reitoria, Conimbriga, 45, 337-357.

Garcia, J. M. (1991), Religiões antigas de Portugal: aditamentos e observações às Religiões da Lusitânia de J. Leite de Vasconcelos: fontes epigráficas, [Lisboa]: Imprensa Nacional-Casa da Moeda $(=R A P)$.

Gonçalves, L. J. R. (2007), Escultura romana em Portugal: uma arte do quotidiano, Mérida: MNAR.

GorGES, J.-G. (1990), Villes et villas de Lusitanie: interactions, échanges, autonomies, in Les Villes de Lusitanie romaine: hiérarchies et territoires, Paris: Centre Nacional de la Recherche Scientifique, 91-121.

Gourevitch, D., RAePsAet-Charlier, M.-Th. (2005), A vida quotidiana da mulher na Roma Antiga, Lisboa: Livros do Brasil.

Grupo Mérida (2003), Atlas antroponímico de la Lusitania romana, Mérida-Bordeaux: Fundación de Estudios Romanos-Ausonius Éditions.

Conimbriga, 55 (2016) 57-89 
Heinzmann, M. (1999), Civitas vel/sive Municipium?: zum inschrftenformular norischer munizipalmagistarte, in González, J. (ed.), Ciudades privilegiadas en el Occidente Romano, Sevilla: Universidad, Secretariado de Publicaciones [etc.], 425-436.

Henriques, L. (1993), As inscrições romanas de Coimbra: recolha bibliográfica, Mun$d a, 25,122-132$.

Hispania Antiqua Epigraphica: suplemento anual de Archivo Español de Arqueologia, Madrid: Consejo Superior de Investigaciones Científicas (=HAE).

Hispania Epigraphica, Madrid: Archivo Epigráfico de Hispania, Universidad Complutense $(=H E p)$.

Hornblower, S., Spawforth, A., Eidinow, E. (2012), The Oxford Classical Dictionary, Fourth edition, Oxford-New York: Oxford University Press $(=O C D)$.

HüBNER, E. (1869), Inscriptiones Hispaniae Latinae, Berolini: apud Georgium Reimerum (Corpus Inscriptionum Latinarum; 2) (= CIL II).

HÜBNER, E. (1892), Inscriptiones Hispaniae Latinae: Supplementum, Berolini: apud Georgium Reimerum (Corpus Inscriptionum Latinarum; 2) (= CIL II).

Kajanto, I. (1965), The Latin Cognomina, Helsinki: Keskuskirjapaino.

Le Roux, P. (1990), Les villes de statut municipal en Lusitanie romaine, in Les Villes de Lusitanie romaine: hiérarchies et territoires, Paris: Centre Nacional de la Recherche Scientifique, 35-49.

Le Roux, P. (1996), Droit latin et municipalisation en Lusitanie sous l'Empire, in Ortiz de Urbina, E., Santos, J. (eds.), Teoria y practica del ordenamiento municipal en Hispania: actas del Symposium de Vitoria-Gasteiz (22 a 24 de Noviembre de 1993), Vitoria: Servicio Editorial, Universidad del Pais Vasco, 239-253.

Le Roux, P. (2010), La péninsule ibérique aux époques romaines: fin du III ${ }^{e}$ s. av. $n$. è. - début du VIe s. de n. è., Paris: Armand Colin.

Le Roux, P., FABre, G. (1971), Inscriptions latines du Musée de Coimbra, Conimbriga, $10,117-130$.

Liverani, P., Spinola, G. (2006), La necropoli vaticana lungo la via Trionfale, Roma: De Luca Editori d'Arte.

LuCas, M. M. (1989), A gens Cadia em Aeminium, Conimbriga, 28, 169-203.

Mantas, V. G. (1992), Notas sobre a estrutura urbana de Aeminium, Biblos, 68, 487513.

Mommsen, Th. (1883), Inscriptiones Bruttiorum, Lucaniae, Campaniae, Siciliae, Sardiniae Latinae, Berolini: apud Georgium Reimerum (Corpus Inscriptionum Latinarum; 10) (= CIL X)

Museu Machado de Castro (1941), Secções de Arte e Arqueologia: catálogo-guia, Coimbra: Coimbra Editora (= MMCSAA).

Navarro Caballero, M., Oria Segura, M., Ramírez Sádaba, J. L. (2003), La onomástica greco-latina: eje 3, in Grupo Mérida, Atlas antroponímico de la Lusitania romana, Mérida-Bordeaux: Fundación de Estudios Romanos-Ausonius Éditions, 408-412.

Oleiro, B. (1955-1956), O criptopórtico de Aeminium, Humanitas, 4-5, 151-160.

Conimbriga, 55 (2016) 57-89 
Prados Martínez, F. (2015), La necrópolis oriental de Baelo Claudia: paisaje y arquitectura funerarios, in Prados Martínez, F., Jiménez Vialás, H. (eds.), La muerte en Baelo Claudia: necrópolis y ritual en el confin del Imperio romano, Cádiz: Universidad, Servicio de Publicaciones, 81-96.

Ribeiro, J. C. (1982-1983), Estudos histórico-epigráficos em torno da figura de L. Iulius Maelo Caudicus, Sintria, 1-2:1, 151-476.

Rodrigues, M. L. (1959-1960), Inscrições romanas do Museu Machado de Castro, Humanitas, 11-12, 112-132.

Santos, F., Carvalho, P. C. (2008), Aspectos do mundo funerário romano na Beira Interior: as estruturas funerárias monumentais da Quinta da Fórnea II (Belmonte): uma primeira abordagem, Conimbriga, 47, 127-143.

Schilling, R. (1979), Rites, cultes, dieux de Rome, Paris: Klincksieck.

Syme, R. (1939), The Roman Revolution, Oxford: The Clarendon Press.

Silva, R. C. (2011), O quarteirão urbano a poente do forum de Aeminium (Coimbra, Portugal): a sua configuração ao longo do séc. I d. C., Conimbriga, 50, 79-99.

Simões, A. F. (1879), Alguns passos num labyrintho: se Coimbra foi povoação romana e que nome teve, Portugal pittoresco, 1, 12-16, 29-32, 43-48, 60-64.

Simões, A. F. (1888), Alguns passos num labyrintho: se Coimbra foi povoação romana e que nome teve, in Escriptos diversos de Augusto Filippe Simões, Coimbra: Imprensa da Universidade, 15-33.

Solın, H. (2003), Die griechischen Personennamen in Rom: ein Namenbuch. 2., völlig neu bearbeitete Auflage. Berlin-New York: De Gruyter.

SusinI, G. (1982), Epigrafia romana, Roma: Jouvence.

Toutain, J. (1907), Les cultes païens dans l'Empire romain, première partie: les provinces latines, $t$. 1: les cultes officiels, les cultes romains et gréco-romains, Paris: Ernest Leroux.

VÄÄNÄNEN, H. (1988), Introducción al latín vulgar, 3. a edición, Madrid: Gredos.

Vallejo Ruiz, J. M. (2005), Antroponimia indígena de la Lusitania romana, Vitoria-Gasteiz: Servicio editorial, Universidad del País Vasco.

Vasconcelos, A. (1896), Aeminium (Coimbra), O Instituto, 43, 215-221.

Veyne, P. (1989), O Império Romano, in Ariès, Ph., Duby, G. (dir.), História da vida privada, 1, Lisboa: Círculo de Leitores, 19-224.

VIVES, J. (1971-1972), Inscripciones latinas de la España romana: antología de 6.800 textos, Barcelona: Universidad [etc.] (= ILER). 


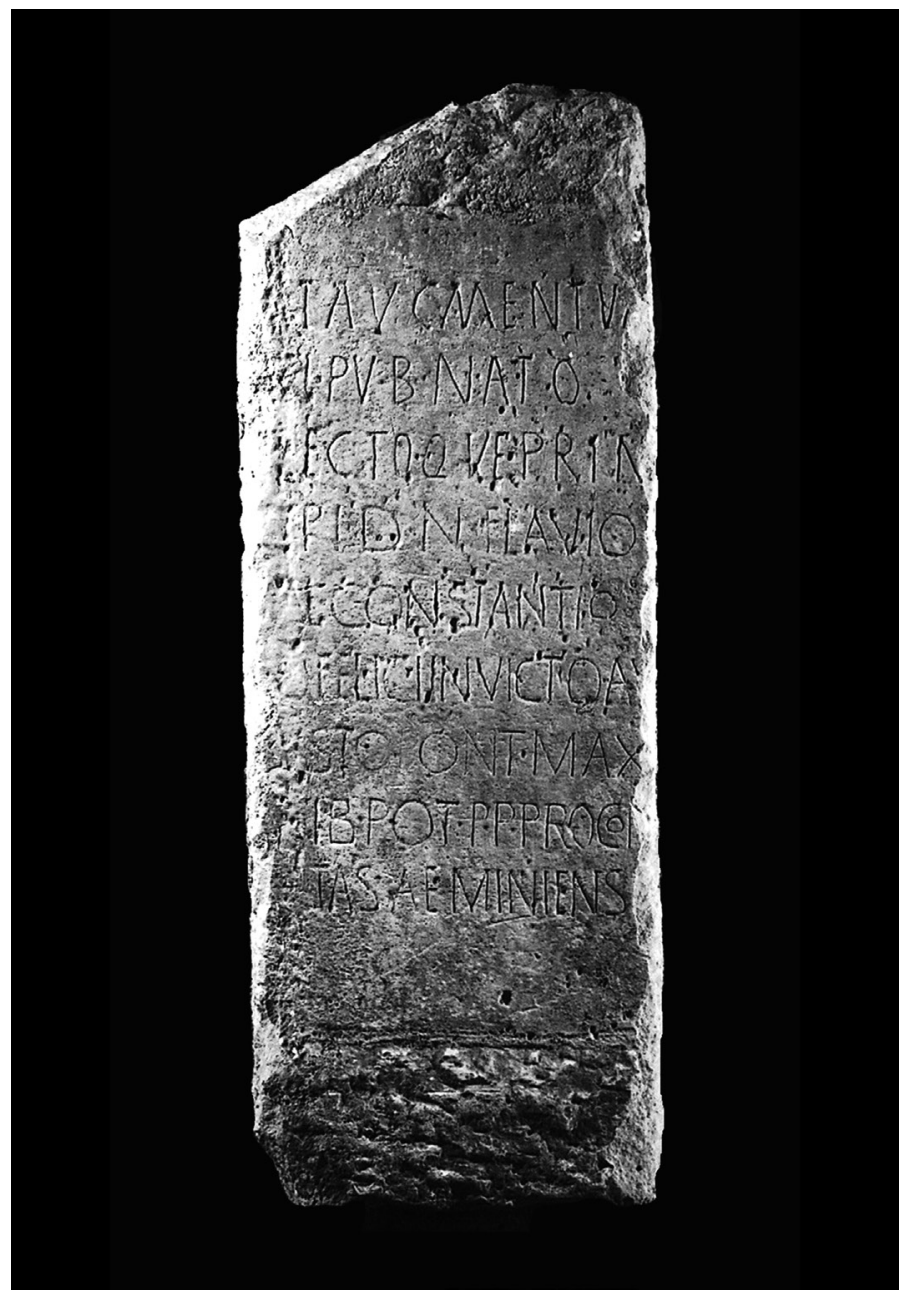

Fig. 1 - Homenagem da ciuitas Aeminiensis a Constâncio Cloro (apud Encarnação 1979, 174, fig. 1). 


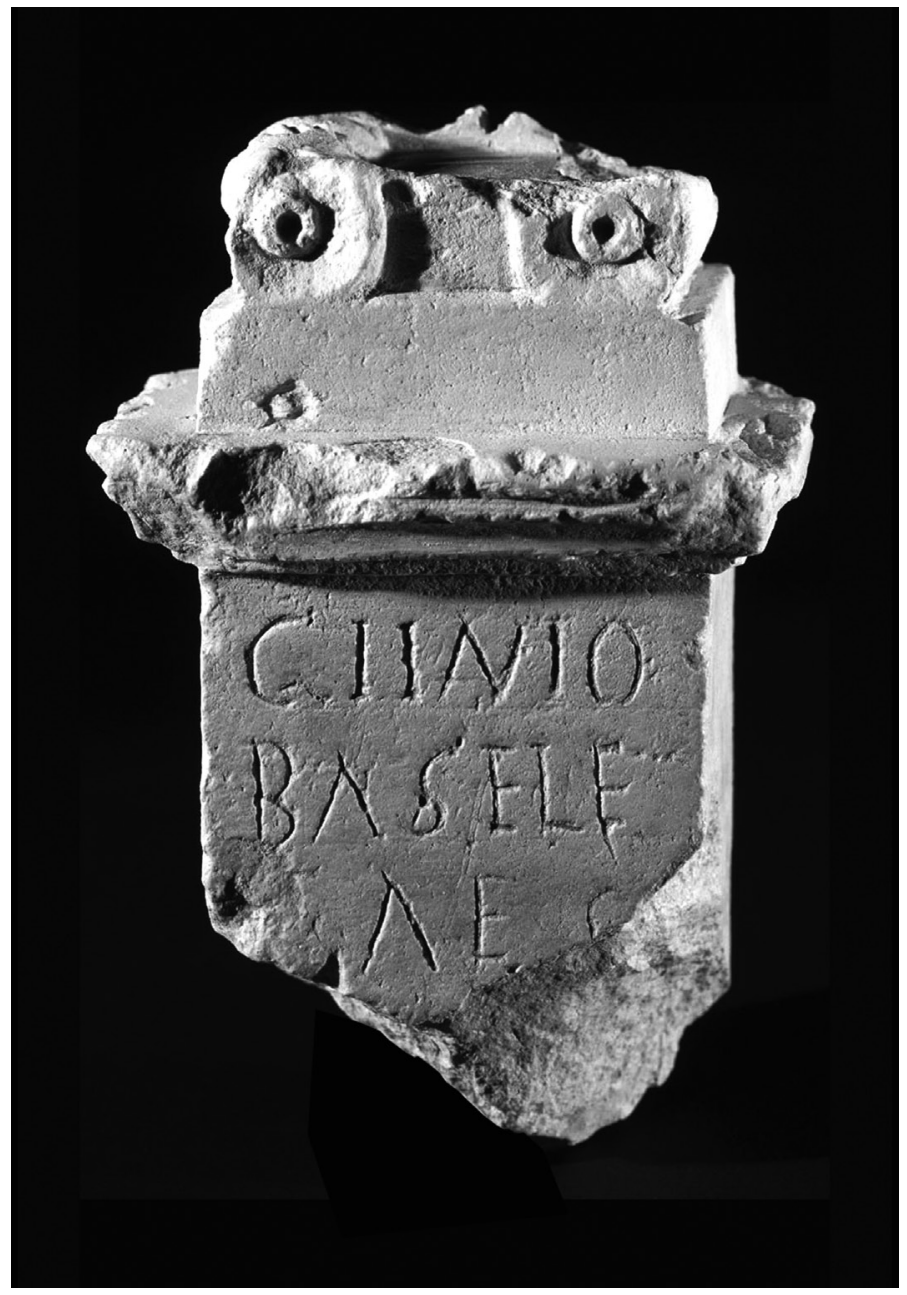

Fig. 2 - Árula ao génio da basílica

(apud Alarcão et alii 2009, 66, fig. 43). 


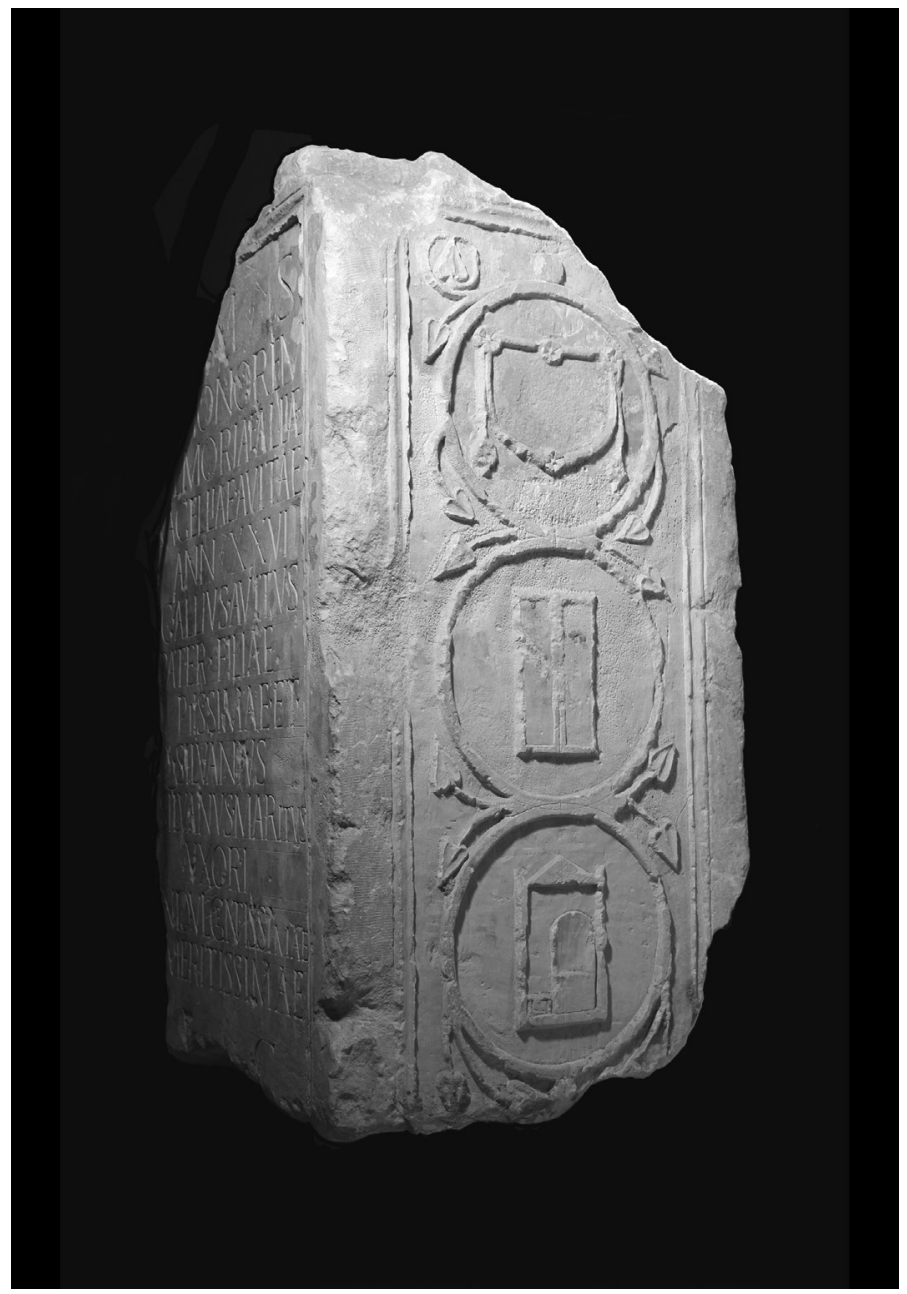

FIG. 3 - Cipo prismático de Allia Vagellia Auita (@ autor). 


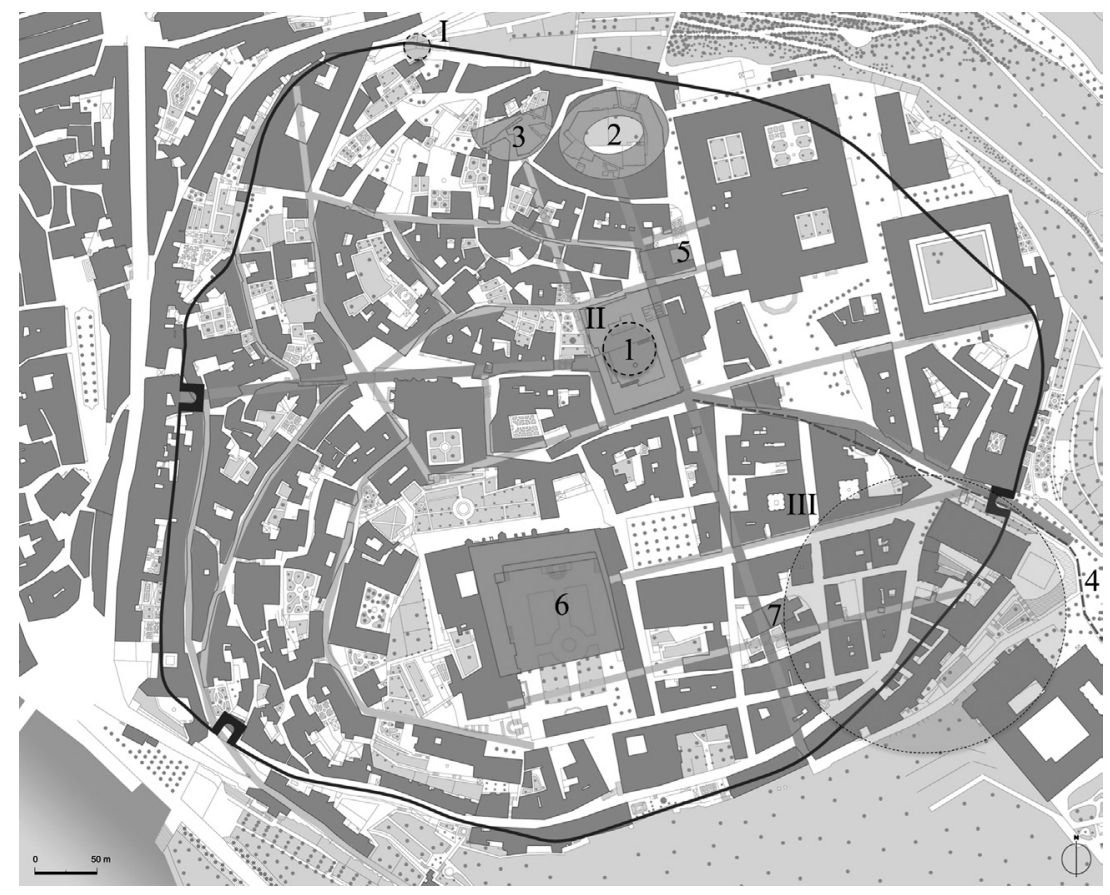

FIG. 4 - Zonamento dos achados das inscrições romanas de Aeminium:

I, torre de Precónio ( $\left.n .^{\circ} 1\right)$; II, criptopórtico (n..$^{o s} 2$ e 15);

III, área entre o antigo castelo e a porta da Traição (n. ${ }^{o s} 3$ a 14).

Base cartográfica apud Alarcão 2008, 65, fig. 35 -Arruamentos da cidade de Aeminium (1. forum; 2. anfiteatro; 3. teatro; 4. aqueduto;

5. templo de culto imperial; 6. alcáçova; 7. igreja de S. Pedro). 